\title{
STUDI KOMPARASI PENDAPATAN USAHA TANI KUBIS BUNGA \\ (Brassica oleracea. L var botrytis sub var. cauliflora DC) DAN PADI \\ (Kasus di Desa Sukapura Kecamatan Rawamerta Kabupaten Karawang)
}

\author{
Netti Nurlenawati \\ Program Studi Manajemen,Fakultas Bisnis, Universitas Buana Perjuangan Karawang \\ Jl. H.S. Ronggowaluyo Telukjambe Timur Karawang \\ Email: netti.nurlenawati@ubpkarawang.ac.id
}

\section{ABSTRACT \\ Comparative Study of Cauliflower and Rice Farm Income in Sukapura Rawamerta Karawang}

This study aimed to analyze the comparison in terms of income, difficulties encountered by the farmers of cauliflower and rice farm, in the Sukapura village, Rawamerta district, Karawang regency, as well as to find the factors causing farmers have low interest on cauliflower.

This research was conducted in Sukapura Village, Rawamerta District, Karawang Regency. This study was conducted from September 2015 to February 2016. The research method used was descriptive method. The data collected through interviews and questionnaires. Analysis of the data used in this research was descriptive analysis to describe difficulties encountered by farmers, and factors causing farmers have low interest on cauliflower in the study area; while to determine the economic benefit level from cauliflower and rice, analysis of revenues, cost, and income was used, followed by analysis of Revenue Cost Ratio and Break Even Point.

The results showed that rice farming is more profitable than cauliflower. The revenues from cauliflower per hectare per growing season was Rp. 24,500,000,- , with a total cost was Rp. 22,268,950,- hence the net income from cauliflower was Rp. 2,231,050,- per hectare per growing season or $R p$. 743,683/month/ha, with $R / C$ ratio 
1.10. While the revenues from rice was Rp. 40,000,000,- per hectare per growing season, with a total cost was Rp. 21,833,963,- therefore the net income from rice was Rp.18,166,037,- per hectare per growing season or Rp.3,027,673 / month / ha, with $R / C$ ratio 1.83 .

In Sukapura Village, cauliflower and rice crops can be cultivated using the cropping pattern sequantial planting (crop rotation). By using this cropping pattern can increase the income of rice farmers, can utilize available irrigation water, also can break the cycle of pests and diseases of rice crops.

Difficulties encountered by farmers which was the main cause of their lack of interest on cauliflower were the price fluctuations on farmer levels, the amounts of pests that attacked the crop, also the high maintenance of cauliflower compared to rice.

Keywords: comparison, cauliflower, rice.

\section{PENDAHULUAN}

Sektor pertanian merupakan sektor yang sangat berperan dalam pembangunan ekonomi nasional. Hal tersebut dapat dilihat dari kontribusinya terhadap Produk Domestik Bruto (PDB), penyerapan tenaga kerja, dan penghasil devisa. Sektor pertanian tidak akan pernah lepas dari fungsinya sebagai sumber utama untuk penyediaan bahan pangan. Dalam meningkatkan ketahanan pangan, tantangan besar saat ini adalah konsumsi masih bertumpu pada beras. Terkait dengan kepentingan sebagian besar penduduk Indonesia ini, maka dari banyaknya petani Indonesia sebagian besar merupakan petani padi sawah.

Selain padi, sayuran merupakan bahan pangan yang juga dibutuhkan oleh masyarakat. Selama ini daerah sentra sayuran terdapat di dataran tinggi, tetapi sejak tahun 2008 Kementerian Pertanian (Kementan) Republik Indonesia telah mengembangkan jenis tanaman sayuran dataran tinggi untuk ditanam di dataran rendah yang dipadukan dengan tanaman pangan lainnya di lima kabupaten di sepanjang Pantai Utara (Pantura) di Provinsi Jawa Barat. Menurut Direktur Budidaya Tanaman Sayuran dan Biofarmaka, Ditjen Hortikultura (2010), menyatakan bahwa 
dataran rendah di sepanjang pantura Jawa Barat memiliki potensi besar untuk dikembangkan dan ditanami tanaman sayuran seperti kubis bunga dan kubis yang berasal dari jenis tanaman dataran tinggi. Kementan membuat terobosan dengan pengembangan Sayuran Dataran Rendah (Sadar) di lima kabupaten, yaitu di Kabupaten Karawang, Subang, Indramayu, Majalengka dan Cirebon, sehingga kini tanaman kubis bunga sudah dibudidayakan di dataran rendah dengan ketinggian 5 sampai 200 meter di atas permukaan laut (Rukmana, 1994 dalam Nurlenawati dkk, 2012 ).

Salah satu jenis sayuran dan telah tersedia jenis kultivar untuk dataran rendah adalah tanaman kubis bunga. Tanaman ini telah banyak dibudidayakan di daerah Indramayu, serta mendatangkan keuntungan bagi petani (Antara, 2011). Berdasarkan hasil wawancara dengan petani kubis bunga di daerah Karawang pada tahun 2012 diperoleh informasi bahwa dari budidaya tanaman kubis bunga seluas $4.000 \mathrm{~m}^{2}$ dihasilkan 7 ton krop dengan harga di tingkat petani Rp. 4.000,00 per kg, sedangkan biaya produksi sebesar Rp. 15.000.000,00. Sehingga diperoleh keuntungan sebesar Rp. 13.000.000,00 atau Rp. 32.500.000,00 per hektar. Dibandingkan dengan budidaya padi di daerah dan tahun yang sama, dari 1 hektar sawah akan dihasilkan rata-rata 6 sampai dengan 8 ton gabah dengan harga Rp. 4.000,00 per kg dengan biaya produksi Rp. 5.000.000,00, sehingga keuntungan yang diperoleh Rp. 19.000.000,00 sampai Rp. 27.000.000,00.

Mengingat adanya perbedaan keuntungan yang cukup tinggi antara usahatani kubis bunga dibandingkan usahatani padi, baik dari keutungan finansial maupun dari segi waktu maka sejak sekitar dua tahun yang lalu banyak petani padi sawah di daerah Karawang yang beralih usahatani dari budidaya padi menjadi budidaya kubis bunga. Namun meningkatnya produksi kubis bunga di dataran rendah tersebut menyebabkan jatuhnya harga kubis bunga.

Dari hasil observasi peneliti, harga kubis bunga di tingkat petani pada bulan Ramadhan tahun 2014 mencapai Rp. 8.000,00 per kg; sedangkan pada bulan Agustus - September tahun 2015 yang bertepatan dengan bulan Ramadhan harga kubis bunga hanya mencapai kisaran Rp. 1.500,00 sampai Rp. 2.500,00. 
Berdasarkan hal ini maka perlu adanya penelitian yang menganalisis dan membandingkan keuntungan yang diperoleh dari usahatani kubis bunga dan usahatani padi di dataran rendah.

Tujuan penelitian ini adalah menganalisis perbandingan dari segi pendapatan, serta kendala yang dihadapi petani dari usahatani kubis bunga dan padi, di Desa Sukapura, Kecamatan Rawamerta Kabupaten Karawang, serta untuk mengungkap faktor-faktor penyebab rendahnya ketertarikan petani di desa tersebut terhadap usahatani kubis bunga.

\section{METODE PENELITIAN}

\section{Lokasi dan Waktu Penelitian}

Penelitian ini dilakukan di Desa Sukapura Kecamatan Rawamerta Kabupaten Karawang. Penelitian ini dilakukan dari bulan September 2015 sampai dengan Februari 2016.

\section{Metode penelitian}

Metode penelitian yang digunakan adalah metode deskriptif. Pengumpulan data dengan wawancara serta menggunakan kuesioner. Pemilihan lokasi penelitian secara purposive sampling dengan pertimbangan bahwa. (1) Desa Sukapura merupakan daerah pesawahan yang memproduksi padi dengan produktivitas 8-10 ton per hektar, (2) para petani di desa ini tidak terlalu tertarik pada usahatani kubis bunga sehingga hanya ada dua orang petani yang membudidayakan tanaman ini.

\section{Variabel Penelitian}

Variabel utama dalam penelitian ini meliputi:

1) Pendapatan usahatani padi dan kubis bunga, dengan indikator sebagai berikut:

a) Produksi. Produksi diperhitungkan untuk satu kali tanam dengan lahan seluas 1 hektar 
b) Harga komoditi di tingkat petani .

c) Penerimaan adalah perkalian antara produksi dengan harga jual $(\mathrm{Rp} / \mathrm{kg})$.

d) Biaya produksi yaitu biaya yang dikeluarkan petani dalam satu kali proses produksi, meliputi biaya tetap dan biaya tidak tetap. Dalam penelitian ini yang diperhitungkan hanya biaya tidak tetap (variable cost) sedangkan biaya tetap (fix cost) yang terdiri dari pajak tanah dan penyusutan alat tidak diperhitungkan. Lahan dianggap sewa sedangkan tanaga kerja dianggap seluruhnya menggunakan tenaga kerja dari luar

Biaya tidak tetap (variabel) yaitu biaya yang langsung mempengaruhi besarnya produksi yang dihasilkan terdiri dari:

- Harga, yaitu harga yang berlaku ditingkat petani (Rp/kg).

- Tenaga kerja, yaitu tenaga kerja yang digunakan. Dalam penelitian ini seluruh tenaga kerja dianggap tenaga kerja dari luar (tidak menggunkan tenaga kerja dalam keluarga). Jumlah tenaga kerja diukur dalam hari orang kerja (HOK).

- Benih, yaitu banyaknya benih yang digunakan oleh petani dalam usahataninya ( Rp/kg).

- Pupuk, yaitu banyaknya pupuk yang digunakan oleh petani dalam usahatani nya $(\mathrm{Rp} / \mathrm{kg})$.

- Pestisida, yaitu banyaknya pestisida yang digunakan oleh petani dalam usahataninya $(\mathrm{Rp} / \mathrm{kg})$.

e) Pendapatan usahatani adalah selisih antara penerimaan dan pengeluaran ( $R p)$.

2) Pemasaran yang memiliki indikator proses pemasaran

3) Kendala-kendala yang dihadapi petani yang memiliki indikator kendala ekonomi, kendala teknis dan kendala non teknis

\section{Metode Analisis Data}

\section{Analisis deskriptif}

Kendala-kendala yang dialami petani dalam berusahatani kubis bunga maupun padi dianalisis secara deskriptif. Kendala tersebut meliputi kendala ekonomi, teknis dan non teknis. 


\section{Analisis pendapatan usahatani}

Untuk melihat tingkat keuntungan ekonomis kubis bunga maupun padi digunakan analisis penerimaan, biaya, pendapatan, kemudian dilanjutkan dengan analisis Revenue Cost Ratio dan Break Event Point.

a) Penerimaan usahatani adalah perkalian antara produksi yang diperoleh dengan harga jual. Pernyataan ini dapat di tulis sebagai berikut.

Untuk menganalisis pendapatan usahatani dilakukan pencatatan terhadap seluruh penerimaan dan pengeluaran usahatani (biaya) dalam satu musim tanam. Pendapatan usahatani merupakan hasil pengurangan antara penerimaan dengan biaya yang dikeluarkan.. Perhitungan pendapatan usahatani dirumuskan secara matematis sebagai berikut:

$$
\mathrm{Pd}=\mathrm{TR}-\mathrm{TC}
$$

\section{Keterangan:}

$\mathrm{Pd}=$ Pendapatan bersih usahatani

TR $=$ Total Penerimaan usahatani

$\mathrm{TC}=$ Total Biaya untuk usahatani

\section{$\mathrm{TR}=\mathrm{Y} \cdot \mathrm{P}_{\mathrm{Y}}$}

Dimana;

$\mathrm{TR}_{\mathrm{i}}=$ Total Penerimaan

$\mathrm{Y}_{\mathrm{i}}=$ Produksi yang diperoleh dalam usahatani

$\mathrm{Py}_{\mathrm{i}}=$ Harga yang berlaku

b) Biaya Total adalah jumlah uang yang dikeluarkan untuk memproduksi dengan rumus:

$\mathrm{TC}=\mathrm{FC}+\mathrm{VC}$ 
Dimana:

$\mathrm{TC}=$ Total Cost

$\mathrm{FC}=$ Fixed Cost

$\mathrm{VC}=$ Variabel Cost

c) Pendapatan adalah selisih antara penerimaan dan semua biaya dengan rumus, yaitu:

$\mathrm{Pd}=\mathrm{TR}-\mathrm{TC}$

Dimana:

$\mathrm{Pd}=$ Pendapatan

$\mathrm{TR}=$ Total revenue

$\mathrm{TC}=$ Total cost

d) Revenue cost ratio adalah perbandingan antara penerimaan dengan biaya-biaya yang dikeluarkan selama proses produksi hingga menghasilkan produk. dengan rumus:

$\mathrm{a}=\mathrm{R} / \mathrm{C}$

Dimana:

$\mathrm{a}=$ Revenue cost ratio

$\mathrm{R}=$ Penerimaan

$\mathrm{C}=$ Cost

Secara teoritis dengan ratio $\mathrm{R} / \mathrm{C}$ :

$>1$ Usahatani tersebut mengalami keuntungan

$=1$ Artinya usahatani tidak untung dan tidak rugi

$<1$ artinya usahatani mengalami kerugian

e) Break Even Point adalah sebuah titik dimana biaya atau pengeluaran dan pendapatan adalah seimbang sehingga tidak terdapat kerugian atau keuntungan. Perhitungan BEP :

- $\quad$ BEP Produksi $=($ Total biaya $) /($ Harga penjualan $)$

- $\mathrm{BEP}$ Harga $=($ Total biaya $) /($ Total produksi $)$ 


\section{HASIL DAN PEMBAHASAN}

\section{Perbandingan Pendapatan Usahatani Kubis Bunga dan Padi di Desa Sukapura Kecamatan Rawamerta Karawang}

Dalam penelitian ini pendapatan usahatani adalah pendapatan bersih dari usahatani yang dikembangkan. Pendapatan bersih merupakan selisih antara penerimaan dan biaya usahatani.

a. Biaya Usahatani Kubis Bunga dan Padi Sawah

Menurut Sukirno (2011) biaya produksi merupakan biaya dari semua pengeluaran yang dilakukan oleh perusahaan untuk mendapatkan faktor-faktor produksi dan bahan baku yang akan digunakan untuk menghasilkan suatu produk. Sedangkan dalam kasus pertanian menurut Soekartawi (1991) biaya produksi adalah nilai dari semua faktor produksi yang digunakan, baik dalam bentuk benda maupun jasa selama proses produksi berlangsung. Berdasarkan hasil penelitian diketahui ratarata biaya untuk usahatani kubis bunga adalah Rp. 22.268.950, sedangkan rata-rata biaya untuk usahatani padi sawah lebih rendah jika dibandingkan dengan biaya produksi usahatani kubis bunga yaitu sebesar Rp. 21.833.963.

\section{b. Penerimaan Usahatani Kubis Bunga dan Padi Sawah}

Dari hasil wawancara dengan petani kubis bunga dan padi sawah diketahui bahwa pada awalnya (dua tahun yang lalu) harga kubis bunga di tingkat petani tinggi mencapai Rp. 4.000,- sampai Rp. 8.000,- per kg, namun pada saat penelitian harga kubis bunga di tingkat petani hanya mencapai Rp. 1500,- sampai Rp. 2.800,- per kg. Dengan memperhitungkan harga per kg lubis bunga Rp. 2.800,- maka penerimaan petani dari hasil penjualan kubis bunga sebesar Rp. 24.500.000,- per hektar per musim tanam.

Harga gabah cukup stabil, tidak terlalu berfluktuasi jika dibandingkan dengan harga kubis bunga. Di tingkat petani harga padi sawah berkisar antara Rp. 4.000,sampai dengan Rp. 5000,- Pada lokasi dan waktu yang sama harga gabah kering 
panen adalah Rp. 5.000,- per kg. Dengan demikian, penerimaan petani dari usahatani padi sawah sebesar Rp. 40.000.000,- per hektar per musim.

Tabel 1. Perbandingan rata-rata penerimaan, biaya dan pendapatan usahatani kubis bunga dan padi per hektar di Desa Sukapura Kecamatan Rawamerta Karawang tahun 2015

\begin{tabular}{|c|l|r|r|}
\hline No & \multicolumn{1}{|c|}{ Uraian } & \multicolumn{1}{c|}{ Kubis Bunga (Rp) } & \multicolumn{1}{c|}{ Padi (Rp) } \\
\hline I & Produksi (ton/ha) & 8.750 & 8.000 \\
\hline II & Penerimaan & 24.500 .000 & 40.000 .000 \\
\hline III & Pengeluaran & & \\
\hline 1. & Biaya sarana Produksi & & \\
\hline & Bibit/benih & 8.750 .000 & 280.000 \\
\hline & Pupuk: & 2.330 .000 & 2.030 .000 \\
\hline & Pestisida & 1.390 .000 & 1.084 .000 \\
\hline 2. & Tenaga kerja & 4.840 .000 & 9.533 .333 \\
\hline 3. & Sewa lahan & 4.000 .000 & 8.000 .000 \\
\hline 4. & Bunga Bank & 958.950 & 906.630 \\
\hline & Total Biaya & 22.268 .950 & 21.833 .963 \\
\hline IV & Pendapatan/musim tanam/ha & 2.231 .050 & 18.166 .037 \\
\hline V & Pendapatan/bulan/ha & 743.683 & 3.027 .673 \\
\hline VI & R/C & 1,10 & 1,83 \\
\hline VII & BEP Produksi (kg) & $7.953,20$ & $4.366,79$ \\
\hline VIII & BEP Harga (Rp/kg) & 2.545 & 2.729 \\
\hline
\end{tabular}

Sumber: Diolah dari data primer

Catatan:

Umur panen (termasuk pengolahan tanah) kubis bunga 3 bulan sedangkan padi sawah 4 bulan. 


\section{c. Pendapatan Usahatani Kubis Bunga dan Padi Sawah}

Pendapatan kotor (gross farm income) itu sebagai nilai produk total usahatani dalam jangka waktu tertentu, baik yang dijual maupun yang tidak dijual. Berdasarkan hasil penelitian di Desa Sukapura Kecamatan Rawamerta Karawang bahwa rata-rata pendapatan usahatani kubis bunga sebesar Rp. 2.231.050 per hektar per musim tanam atau Rp. 743.683,-- per hektar per bulan, sedangkan rata-rata pendapatan usahatani padi sawah adalah Rp. 18.166.037 per hektar per musim atau Rp. 3.027.673 per hektar per bulan.

\section{d. Perhitungan Revenue Cost Ratio Usahatani Kubis Bunga dan Padi Sawah}

Nilai R/C ratio kubis bunga sebesar 1,100 hal ini dapat diartikan bahwa setiap penggunaan biaya sebesar Rp.1 akan mendapatkan penerimaan sebesar Rp. 1,10, hal ini menunjukkan bahwa usahatani kubis bunga layak untuk dikembangkan. Di pihak lain nilai $\mathrm{R} / \mathrm{C}$ ratio padi sawah sebesar 1,83 hal ini dapat diartikan bahwa setiap penggunaan biaya sebesar Rp 1 akan mendapatkan penerimaan sebesar Rp 1,83, sehingga usahatani padi sawahpun layak untuk dikembangkan. Dari analisis R/C ratio tersebut tampak usahatani padi sawah lebih layak dikembangkan di Desa Sukapura Kecamatan Rawamerta Kabupaten Karawang dibandingkan dengan usahatani kubis bunga.

\section{e. Perhitungan Break Even Point Usahatani Kubis Bunga dan Padi Sawah}

Break Even Poin adalah sebuah sebuah titik dimana biaya atau pengeluaran dan pendapatan adalah seimbang sehingga tidak terdapat kerugian atau keuntungan. Dari hasil perhitungan BEP Produksi usahatani kubis bunga sebesar 7.953,20 kg, sedangkan BEP harga sebesar Rp. 2.545 artinya pada saat produksi kubis bunga mencapai 7.953,20 kg dengan harga sebesar Rp. 2.545 per $\mathrm{kg}$ satu kali proses produksi menyatakan bahwa usahatani kubis bunga di Desa Sukapura, telah melampaui titik impas (Break Even Point). Pada saat produksi kubis bunga melimpah harga per $\mathrm{kg}$ hanya mencapai Rp. 1.500,- sampai dengan Rp. 2.500,sehingga petani mengalami kerugian. 
Break Even Point (BEP) Produksi usahatani padi sawah sebesar 4.366,79 kg, sedangkan BEP harga sebesar Rp. 2.729 artinya pada saat produksi kubis bunga mencapai 4.366,79 kg dengan harga sebesar Rp. 2.729 per kg satu kali proses produksi menyatakan bahwa usahatani kubis bunga di Desa Sukapura, telah melampaui titik impas (Break Even Point). Kisaran harga gabah per kg di Desa Sukapura Kecamatan Rawamerta antara Rp. 4.500 sampai dengan Rp. 5.500,-. Dengan nilai BEP Harga Rp. 2.729,-- maka pada saat produksi stabil petani padi sawah akan mendapatkan keuntungan.

\section{Kendala - kendala yang Dihadapi oleh Petani Kubis Bunga di Desa Sukapura Kecamatan Rawamerta Kabupaten Karawang}

\section{a. Iklim}

Tanaman kubis bunga merupakan tanaman yang berasal dari daerah sub tropis. Di Indonesia biasanya dibudidayakan di dataran tinggi, dengan suhu yang rendah dan kelembaban relatif tinggi. Walaupun saat ini telah dikembangkan kultivar kubis bunga yang toleran terhadap suhu tinggi, namun produksinya lebih rendah dibandingkan kultivar dataran tinggi, baik dari segi kuantitas maupun kualitas. Sedangkan bagi tanaman padi daerah Karawang merupakan lingkungan yang sangat cocok untuk tanaman ini, sehingga tidak ada kendala dalam mencapai potensi hasil.

\section{b. Perubahan harga}

Salah satu aspek dalam studi kelayakan usahatani adalah aspek pasar. Menurut Husnan dan Suwarsono (2000) aspek pasar tersebut antara lain permintaan, penawaran dan harga. Ketiga hal tersebut saling berkaitan. Pada saat permintaan tinggi, penawaran rendah, maka harga akan naik. Sebaliknya saat permintaan sedikit, penawaran tinggi maka harga akan jatuh. Keadaan ini menyebabkan fluktuasinya harga. Kadangkala fluktuasi harga tersebut disebabkan oleh karakter komoditi yang diusahakan. Tanaman kubis bunga merupakan tanaman sayuran yang memiliki karakteristik tidak tahan disimpan, sehingga apabila petani panen sayuran ini secara bersamaan akan menyebabkan hasilnya melimpah di pasaran. Pada saat ini biasanya 
harga menjadi sangat rendah. Sebaliknya jika jumlah kubis bunga hanya sedikit di pasaran, maka harga menjadi tinggi. oleh karena itu harga kubis bunga sangat fluktuatif tergantung pada jumlah produk di pasaran. Keadaan ini menyebabkan petani tidak dapat memprediksi pendapatan yang akan diterima.

Berbeda halnya dengan padi, mengingat beras merupakan makanan pokok bagi masyarakat Indonesia maka Pemerintah mengatur harga gabah. Selain itu gabah juga dapat disimpan dibandingkan dengan kubis bunga atau sayuran lainnya, sehingga harga gabah lebih konstan jika dibandingkan dengan harga kubis bunga.

\section{c. Organisme pengganggu tanaman}

Di dataran rendah serangan organisme pengganggu tanaman sangat tergantung pada musim. Saat musim penghujan gulma dan penyakit umumnya menyerang tanaman sayuran, sehingga petani jarang menanam kubis bunga pada musim penghujan. Sebaliknya pada musim kemarau organisme pengganggu yang menyerang tanaman sayuran adalah hama. Pada tanaman kubis bunga dataran rendah hama utamanya adalah hama tikus dan ulat Croci dan atau ulat Plutella. Serangan ketiga jenis hama tersebut dapat menurunkan hasil sampai 30\%. Berdasarkan hal itu biaya untuk pembelian pestisida lebih tinggi dibandingkan dengan tanaman padi.

\section{d. Pemeliharaan}

Tingginya serangan hama dan penyakit maupun keberadaan gulma pada pertanaman kubis bunga menyebabkan petani harus melakukan pemeliharaan yang intensif. Pada usahatani tanaman padi sawah petani dapat mengandalkan tenaga kerja untuk melakukan pemeliharaan, sedangkan pada tanaman kubis bunga selain menggunakan tenaga kerja untuk menyemprot hama juga perlu pemantauan ekstra dari petani.

\section{e. Budaya kerja serta keterbatasan keterampilan petani.}

Pada umumnya petani pemilik pada usahatani padi sawah di Desa Sukapura Kecamatan Rawamerta Kabupaten Karawang tidak melakukan kegiatan budidaya tanaman tetapi sepenuhnya mengandalkan tenaga kerja luar keluarga. Kegiatan tersebut meliputi pengolahan tanah, penanaman, pemeliharaan (penyemprotan hama 
penyakit, penyiangan gulma) serta panen. Pemantauan yang dilakukan petani pada usahatani padi sawah biasanya kurang intensif. Berbeda dengan petani kubis bunga, walaupun kegiatan budidaya dilakukan oleh tenaga kerja di luar keluarga namun tetap harus dipantau secara intensif, karena tanaman ini lebih rentan terhadap gangguan lingkungan baik biotik maupun abiotik.

Selain itu para tenaga kerja belum terbiasa mengerjakan budidaya tanaman sayuran. Misalnya pada saat penanaman, umumnya bibit kubis bunga ditanam kurang dalam sehingga bibit yang baru ditanam menjadi layu kemudian mati. Pada saat penyemprotan hama ulat, umumnya tidak kena sasaran karena ulat biasanya berada di permukaan bawah daun.

\section{f. Manajemen usahatani}

Menurut Kuntjoro (2002) salah satu aspek manajemen merupakan manajemen dalam penjadwalan penyelesaian usaha. Umumnya petani di Indonesia akan tertarik mengusahakan suatu komoditi jika menguntungkan. Pada saat petani lain berhasil atau mendapat keuntungan yang besar, maka petani yang lain akan mengikuti usahatani tersebut tanpa mempertimbangkan pola tanam yang akan mempengaruhi harga.

Dari keenam kendala tersebut, yang menjadi kendala utama sekaligus penyebab utama rendahnya ketertarikan mereka dalam usahatani budidaya kubis bunga adalah fluktuasinya harga kubis bunga di tingkat petani dan banyaknya hama yang menyerang tanaman ini, serta perlunya tingkat pemeliharaan yang lebih intensif dibandingkan dengan budidaya padi sawah. Mereka mengganggap pemeliharaan yang harus dilakukan secara intensif tidak sebanding dengan rendahnya pendapatan yang mereka terima.

\section{KESIMPULAN}

Usahatani padi sawah di Desa Sukapura Kecamatan Rawamerta Kabupaten Karawang lebih menguntungkan dibandingkan dengan usahatani kubis bunga. Tingkat penerimaan kubis bunga per hektar per musim tanam adalah Rp. 24.500.000,- dengan total biaya sebesar Rp. 22.268.950,- sehingga pendapatan riil 
yang diterima petani dari pertanian kubis bunga adalah Rp. 2.231.050 per hektar per musim tanam atau Rp. 743.683/bulan/ha dengan $\mathrm{R} / \mathrm{C}$ ratio sebesar 1,10. Sedangkan tingkat penerimaan usahatani padi sawah per hektar per musim tanam adalah Rp. 40.000.000,- dengan total biaya sebesar Rp. 21.833.963,- dengan demikian pendapatan bersih dari usahatani padi adalah Rp18.166.037,- per hektar per musim tanam atau 3.027.673/bulan/ha dengan $\mathrm{R} / \mathrm{C}$ ratio sebesar 1,83.

Kendala-kendala yang dihadapi oleh petani yang menjadi penyebab utama rendahnya ketertarikan mereka dalam usahatani budidaya kubis bunga adalah fluktuasinya harga kubis bunga di tingkat petani dan banyaknya hama yang menyerang tanaman ini, serta perlunya tingkat pemeliharaan yang lebih intensif dibandingkan dengan budidaya padi sawah.

\section{SARAN}

Dari hasil penelitian ini dapat disarankan hal-hal sebagai berikut:

1. Agar harga kubis bunga tidak fluktuatif sebaiknya ada pengaturan pola tanam, sehingga waktu panen tidak bersamaan.

2. Di Desa Sukapura Kecamatan Rawamerta Kabupaten Karawang tanaman kubis bunga dan tanaman padi sawah dapat diusahakan menggunakan pola tanam Sequantial planting (tanaman bergiliran). Menggunakan pola tanam ini dapat meningkatkan pendapatan petani padi sawah, memanfaatkan air irigasi yang masih tersedia, serta memotong siklus hama penyakit tanaman padi.

\section{DAFTAR PUSTAKA}

AAK. 2009. Break Even Point (BEP), ilmu manajemen, http//:www. wordpress.com, diakses, 18 Januari 2015.

. 2005. Definisi Usahatani, http//:www.scribd.com/ Ekonomi Pertanian, Diakses, 14 September 2012. 
Antara. 2011. Harga Bunga Kol di Indramayu Rp. 5.000 per Kg. http://antarajawabarat.com. Diakses tanggal 13 Februari 2012

Badan Agribisnis Departemen Pertanian. 2009. Investasi Agribisnis Komoditi Unggulan

Cahyono. 2011. Budidaya kubis bunga. Penebar Swadaya. Jakarta

Daniel, M. 2002. Pengantar Ekonomi Pertanian. Bumi Aksara. Jakarta.

Gujarati, D. N. 2007. Dasar-dasar Ekonometrika. Salemba Empat. Jakarta.

Hantari, I. A. 2007. Analisis Pendapatan dan Produksi Usahatani Padi Swaah Lahan Sempit di Desa Sitimulyo Kecamatan Piyungan Kabupaten Bantul. Tesis. Fakultas Ekonomi dan Manajemen IPB. Bogor.

Kuntjoro, 2002. Kelayakan Finansial Proyek. Jurusan Ilmu-Ilmu Sosial Ekonomi, Fakultas Pertanian. Institut Pertanian Bogor. Bogor.

Nurlenawati, N., S. S., Purnomo dan E., Fitriyah. 2012. Pengaruh jarak tanam dan dosis kompos limbah media jamur merang terhadap pertumbuhan dan hasil tanaman kubis bunga (Brassica oleracea L.Var. botrytis sub var. cauliflora DC) dengan teknologi mulsa di dataran rendah pada musim kemarau. Solusi, 11(26):1-15.

Soekartawi, 2003. Prinsip Ekonomi Pertanian. PT. Rajagrafindo Persada, Jakarta.

Sukirno, Sadono. Teori Pengantar Mikroekonomi, Edisi 3, PT. Raja Grafindo Persada, Jakarta, 2008. 